\title{
2 Karl Marx and the Capabilities Approach
}

\author{
David Leopold
}

Ultimately, the process of economic development has to be concerned with what people can or cannot do, e.g. whether they can live long, escape avoidable morbidity, be well nourished, be able to read and write and communicate, take part in literary and scientific pursuits, and so forth. It has to do, in Marx's words, with 'replacing the domination of circumstances and chance over individuals by the domination of individuals over chance and circumstance'.

(Amartya Sen $)^{1}$

\subsection{Historical Connections}

The connections between Karl Marx (1818-83) and the capabilities approach are occasionally invoked but not much explored. Marx is typically mentioned in passing, in the role of a distinguished forerunner - his function seemingly to lend a little authority to proceedings, but not to participate very directly in the discussion. He shares this role, as part of a dignified (if slightly idiosyncratic) founding triumvirate, alongside Aristotle and Adam Smith.

Amartya Sen has often identified Marx as a historical forerunner, suggesting, for example, that ' $[\mathrm{t}]$ he roots of this approach go back', at least, to Marx (along with Adam Smith). ${ }^{2}$ And Martha Nussbaum - although best-known for pressing Aristotle's claims to be admitted to the relevant pantheon - identifies the idea of fundamental 'entitlements' in the capabilities approach, in particular, as tracing 'its origins to the early Marx's conception of truly human functioning'. 3

Despite these generous acknowledgements, Marx remains rather on the margins. For example, in a recent historical survey of European philosophical influences on the capabilities approach, Nussbaum mentions Marx only once in passing, and his ideas receive no subsequent discussion. ${ }^{4}$ Nussbaum's narrative begins, appropriately enough, with the work of Aristotle (and his ideas of flourishing, choice and vulnerability), together with a necessary corrective provided by the Stoics (who, unlike Aristotle, understood equal worth and dignity). These ideas are then said to have been rediscovered, and refined, in the seventeenth and eighteenth centuries,

1 Sen 1997a: 497, quoting Marx and Engels 1976: 438.

2 Sen 1997a: 512 n. 6. See also Sen 1988: 16. ${ }^{3}$ Nussbaum 2006: 277.

4 Nussbaum 2011a: 124. 
particularly by Smith and Thomas Paine (who appreciated the importance of governmental action for the development of human capabilities). The nineteenth and early twentieth centuries saw the resulting bundle of ideas passed down through John Stuart Mill (who recognized the previous damage done to the opportunities and capacities of women), to T. H. Green (who mobilized Aristotelian ideas against Utilitarians and libertarians) and Ernest Barker. At this point, we are told, these ideas formed part of the intellectual environment of the University of Cambridge, where they might well have percolated down to the young Sen. ${ }^{5}$

I suspect that this historical narrative understates the place of Marx, and in what follows I have two basic ambitions. First, I want to say a little more about his connections with the capabilities approach; not least, in an attempt to clarify and deepen our understanding of those possible links. Second, and more tentatively, I would like to shift the focus slightly, away from the historical roots and towards the present day, trying to move Marx a little closer to the 'efficient', and not merely 'dignified', part of the discussion.

\subsection{Some Scepticism}

The association of Marx and the capabilities approach will strike some as improbable. In particular, readers might have concerns about anachronism, morality and clarity.

By 'anachronism' I mean the thought that it is an error to describe the beliefs of historical figures in terms which would have been unavailable to those figures (as in familiar and - on this account - misguided portraits of John Locke as a steadfast advocate of 'liberal' views). The purported mistake is that rather than capturing the historical meaning intended by the writer in question, one is attributing to them 'a meaning that they could not have intended to convey' in their various writings, because that meaning was unavailable at the time. ${ }^{6}$ Given the complexity of these issues, and the limitations of space here, let me simply accept the purported error, but suggest that it can easily be avoided by distinguishing between the authorial intention and the historical impact of their work. Thus, whilst Marx, since he was not familiar with the capabilities approach, could not have intended his work as a contribution to its development, it does not follow that his work cannot have played some role in that development. The capability account has a history, and there is evidence that Marx was a part of it. In addition, there are, of course, less-historical connections here, and engaging with these might also be fruitful; not least, helping to clarify the purposes and proper interpretation of the capabilities approach.

By 'morality' I mean the thought that the capabilities approach constitutes an answer to a set of problems that Marx was uninterested in, or even hostile towards. This concern can take a variety of forms, but might most probably claim that, whilst the capabilities approach is a theory of justice, Marx rejects justice concerns (for

\footnotetext{
5 Ibid.: $125 .{ }^{6}$ Skinner 2002: 61.
} 
example, as ideological in his pejorative sense). These are complicated issues, but such a claim looks contestable in both directions. The intellectual commitment at the heart of the capabilities approach - roughly speaking, that the freedom to achieve valuable functionings is the appropriate standard of advantage - can be developed in a number of directions, of which contributing to a theory of justice is only one. Others might include: advancing comparative assessments of the quality of life; evaluating institutions and practices in terms of (non-justice) values (such as 'efficiency') conceptualized in a suitably 'capabilitarian' manner; rethinking the character of social practices such as education, and so on. ${ }^{7}$ In addition, there is no scholarly consensus regarding Marx's lack of interest in questions of justice. The literature here is considerable, but many distinguished scholars recognize Marx's normative concerns as extending to questions of social justice (in addition to non-moral goods, and moral concerns other than justice). ${ }^{8}$ In short, even if the capabilities approach were (as it is not) concerned only with social justice, that would not, in itself, constitute a good reason for being sceptical of its having connections with Marx's views.

By 'clarity', I mean the thought that talk of 'forerunners', 'precursors', and so on, can look horribly vague. Thus far, I have spoken of 'connections' and 'links' between Marx and the capabilities approach. In search of some precision, let me distinguish between two relevant possibilities: that (theoretically) there is an 'affinity' (that is, some similarity of character or contents) between Marx's views and those of modern advocates of the capability approach; and that (historically) Marx's views 'influenced' (that is, shaped, or had an effect on) those of modern advocates of the capabilities approach. Affinity and influence can be complexly related. One might variously have affinity but no influence (as in cases of independent discovery); influence but no affinity (as when my views are formed in rejection of yours); and both affinity and influence (which we might call positive influence). All of which is to clarify that it is affinity, rather than influence, that I focus on here. Indeed, I think of affinity as typically having some priority here; claims about influence usually coming along later, in order to explain, or cast doubt on, affinity.

This is perhaps a happy result, since serious historical work of the kind needed to establish positive influence is especially difficult with living authors and moving targets. However, I should stress that I do not avoid such claims here because of any scepticism about their plausibility. Indeed, I have already suggested that Nussbaum's recent historical narrative might understate the possible place of Marx; not least, on the intellectual development of Sen (the modern pioneer, and best-known defender, of the capabilities approach). Marx seems to have influenced Sen both directly (as the latter read the former), and indirectly (as Sen was exposed to Marx's ideas through contact with others). First, Sen was familiar with Marx's work from an early stage; Sen's writings contain plenty of references to Marx texts, both obscure and well-known (the first volume of Capital and the Critique of the

7 See Robeyns 2016.

8 See, e.g., Cohen 1988: ch. 14; and Geras 1986: ch. 1. For dissenters, see Wood 1981: ch. 9; and Lukes 1987. 
Gotha Programme are perhaps most frequently quoted). ${ }^{9}$ Second, there are several indirect conduits of possible exposure to Marx's ideas, in both Kolkata and Cambridge (where much of Sen's early intellectual evolution took place). In Kolkata, Amiya Dasgupta - a brilliant economist with a deep interest in the history of the discipline - looks to be a key figure; he was the joint supervisor of Sen's doctorate and much else besides. ${ }^{10}$ In Cambridge (and especially Trinity College), the relevant suspects would include Joan Robinson (Sen's other doctoral supervisor and perhaps a slightly pricklier presence), the communist Maurice Dobb and (Dobb's good friend) the wholly remarkable Piero Sraffa (even in this distinguished company, Sraffa can be called wholly remarkable). ${ }^{11}$ However, these questions of influence are not pursued further here. ${ }^{12}$

\subsection{Human Flourishing}

I have described the central commitment of the capabilities approach as affirming the freedom to achieve valuable functionings as the appropriate standard of advantage. That approach focuses not on the resources (or income, or primary goods) that persons have, nor on the satisfaction (or utility or welfare) that they experience, but rather on their capabilities. These capabilities are typically understood as a person's effective freedom to achieve valuable states of 'being' and 'doing'. These beings and doings can take more or less basic forms; a person's real opportunities, so to speak, might include both avoiding starvation and achieving emotional fulfilment. The subset of these opportunities which consist of the person's actual beings and doings are their achieved functionings. (Whether capabilities or functionings should be the focus of attention is much discussed, and might depend, in part, on the use to which the approach is being put.) It is sometimes suggested that we think of the relevant beings and doings here as the causal intermediaries between resources and satisfaction (located, so to speak, after the former and before the latter). The capability approach recognizes the ways in which individuals differ in their ability to convert resources (or income, or primary goods) into these functionings. The possible conversion factors here are many; including individual physical differences, the natural environment, social arrangements and cultural attitudes. ${ }^{13}$ More generally, we might say that the capabilities approach maintains that what matters is less the means than what we can do with them, and that, importantly, this will vary between individuals. Finally, the approach also recognizes the importance of freedom. The precise relations here are complicated and contested, but freedom can be located both in the idea of opportunity

9 The most obscure perhaps Athar Hussain's English translation of Marx's 'Marginal Notes on Adolf Wagner' from the Althusserian journal Theoretical Practice in the early 1970s. See Sen 1997b: 442.

10 See Sen 1994. ${ }^{11}$ On Sraffa, see Sen 2003.

12 For discussion, see Sánchez Garrido 2008: pt. 3. Eric Hobsbawm - a 'magnificent historian and one of the greatest of human beings' (Sen's words at the memorial event in New York entitled 'Hobsbawm's Twentieth Century') - should also be mentioned. Sen first read Hobsbawm's work in Kolkata, they met in Cambridge, and became good friends and near neighbours in London.

13 See Sen 2009: $254 \mathrm{ff}$. 
(the existence of a range of valuable alternatives), and in the idea of individuals choosing freely (as itself a valued functioning).

Marx was obviously not familiar with this developed theoretical framework, but nonetheless it resonates with certain threads in his work. In seeking to substantiate that claim, I focus mainly on the account of human flourishing found in Marx's socalled 'early writings'. These texts were written in the early 1840s, when Marx was living in Kreuznach and then Paris; only a few were published at the time, and collectively they only became well-known a century later. I adopt this approach because the discussion of human flourishing in these texts is especially rich, and because - notwithstanding the many and varied changes elsewhere in his thought I maintain that Marx does not subsequently change his views significantly on this issue. (This is not to deny the possibility of changes of emphasis within, or to the rationale of supporting arguments for, this basic picture of human flourishing.) However, little I argue for here depends on this latter (biographical) claim. Those holding very different views about Marx's subsequent intellectual evolution can simply read my references to 'Marx' as references to 'the young Marx'.

For Marx, the ways in which individuals act and interact - with each other and with the natural world - are, in part, an expression, and revelation, of their essential human powers (their central human capacities and their associated drive to develop and deploy them). ${ }^{14}$ When (both individually and collectively) humankind have actively developed and deployed these essential human powers to a sufficient extent, they can be said to flourish, to lead fully human lives.

From his discussion of human flourishing, we can unpack Marx's understanding of what individuals need to be and do if they are to lead fully human lives. $\mathrm{He}$ identifies some functionings as more important and valuable than others, generating what might be described, without much strain, as a list of 'central capabilities'. Marx understands the associated functionings as involving the realization of our essential human powers, and as constituting the good life for humankind.

This model of human flourishing plays a crucial role in Marx's emancipatory project. It provides a normative benchmark for both the critique of existing classdivided societies, and the construction of a rational and humane alternative. There is little doubt about the strength and extent of Marx's anger at the ways in which the existing world frustrates human flourishing; the contemporary organization of work, for instance, is said to produce 'stunted monsters' rather than fully human beings. ${ }^{15}$ In contrast, in the humane and rational (communist) future, he suggests that individuals will finally become 'species beings' - that is, they will actualize their essential human powers - in their 'empirical life'. ${ }^{16}$

There is much that might be said about Marx's model of human flourishing, and its connections with the capabilities approach. Here I note three shared concerns, before turning to examine some formal and substantive affinities more closely.

\footnotetext{
${ }^{14}$ See, e.g., Marx 1975e: 301. ${ }^{15}$ Marx 1975c: $193 .{ }^{16}$ Marx 1975a: 168.
} 
First, Marx acknowledges the importance of external (social and natural) conditions for human flourishing. Our essential human powers have internal and external conditions for their development and deployment; we are creatures of a particular kind and require an environment of a particular kind in order to develop and flourish. These external conditions are 'indispensable' to the 'manifestation and confirmation' of our essential human powers, but the historical route to human flourishing is a complex one for Marx. ${ }^{17}$ Class-divided societies, for instance, constitute both a necessary stage in the development of these essential powers, and a barrier to their full and free deployment.

Second, Marx stresses the centrality of freedom to human flourishing. The development and deployment of our essential human powers takes the form of selfrealization, and this self-realization, we might say, is both of and by the self. The suggestion that self-realization is also by the self is intended to capture the idea that this expression of our essential powers is the result of self-directed activity. ${ }^{18}$ So understood, human flourishing would seem to require both the availability of a range of different opportunities, and that individuals choose authentically between them. In one well-known passage, the communist future is said to be organized in such a way as 'makes it possible for me to do one thing to-day and another tomorrow' - in Marx's words, 'just as I have a mind'. ${ }^{19}$ In valuing both the availability of options, and the idea of individuals choosing for themselves, freedom is thus built into his basic model of human flourishing. It is worth noting that Sen is familiar with this passage, and quotes it in support of his claim that ' $[t]$ he importance of freedom in judging a person's life was sharply emphasised by Marx'. 20

Third, Marx has some appreciation of 'conversion' issues. In the Critique of the Gotha Programme, for instance, he comments on some limitations of the so-called 'contribution principle' (a distributive principle which rewards individuals in proportion to their contribution to the social product). One problem with this kind of standard, he notes, is that it treats unlike people alike, ignoring the ways in which our 'individual endowments' vary (I might, for instance, have had to push myself much harder in order to make the same contribution as you). Another problem is that - since, if we contribute the same, then we receive the same - it fails to understand that equal resources do not yield equality in what matters. For instance, giving the same income to the two workers, only one of whom has children, means that 'one will in fact receive more than another, one will be richer than another'. ${ }^{21}$ Marx's comments demonstrate both a concern to locate the correct locus of equality, and a nascent critique of 'resourcism' (for its 'fetishism' of means). What matters, he suggests, is not that individuals get the same income, but that they are all equally able to flourish.

\footnotetext{
17 Marx 1975e: 336. ${ }^{18}$ See also McMurtry 1978: ch. 1. ${ }^{19}$ Marx and Engels 1976: 47.

20 Sen 1988: 37 n. 18. 21 Marx 1989: 87.
} 


\section{$2.4 \quad$ Formal Affinities}

The capabilities approach has a number of formal threads. It is, for example, often described as 'non-subjective', 'pluralistic' and 'individualistic'. I will say something about how these terms are usually understood, and offer some parallels with Marx's work.

First, the capabilities approach is often characterized as hostile towards 'subjective' alternatives; that is, those competing accounts which rely wholly on mental states in their assessment of advantage. For instance, Sen criticizes consequentialist theories, such as Utilitarianism, which judge states of affairs solely in terms of pleasure, or happiness, or desire satisfaction (paying, as he observes 'no direct attention to such things as the fulfilment or violation of rights, duties, and so on'). ${ }^{22}$ One of Sen's several worries about such accounts is that they fail to appreciate the ways in which the malleability of 'pleasure' or 'desire' can makes them an inadequate guide to deprivation and disadvantage. ${ }^{23}$ Consider, for instance, that the exploited and oppressed often adjust their desires in order to make life in adverse conditions more bearable. Their consequent resignation or contentment cannot legitimately determine the normative judgement here (the happy slave, we want to say, is still a slave). The erroneous thought here is not that mental states are important, but that they are the only thing that matters.

Marx's enthusiasm for meeting human needs (rather than, say, desires and wants), also appears to reflect a conviction that what matters in the assessment of disadvantage is what people are, and can do, not merely how content they might or might not be. It is noticeable that his famous characterization of alienation in work involves four 'objective' separations (discussed below) and makes only secondary reference to feelings or beliefs. Indeed, that subjective dimension is often seemingly discounted precisely because of doubts about its origins. In The Holy Family, for instance, Marx suggests that both the propertied class and the proletariat 'present the same human self-estrangement', even though the former typically 'feels at ease and strengthened' in that estrangement. ${ }^{24}$ The fact that capitalists can be 'happy in their alienation' does not diminish their objective estrangement (only perhaps their insight into its nature and extent). More generally, Marx is aware that the malleability of desires and preferences can make it implausible to put too much normative weight on them. Consider, for example, his view that the prevalence of (false and misleading) religious beliefs are the result, in part, of the (albeit inadequate) consolation that they offer; like opium, religious beliefs offer an 'illusory happiness' as we traverse the 'vale of tears' that is life in class-divided society. ${ }^{25}$ That we develop consoling beliefs in response to flawed social circumstances makes the resulting satisfaction an inadequate measure of how well our lives are actually going. ${ }^{26}$

22 Sen 2001: 59. For some complexities here, see Qizilbash 2006 and Sumner 2006.

23 Sen 2001: 63. ${ }^{24}$ Marx and Engels 1975: 36. ${ }^{25}$ Marx 1975b: 176.

26 For an interesting comparison between Sen and Marx in this context, see Qizilbash 2016. 
Second, the capabilities approach is also often characterized as a 'pluralistic' theory. No doubt, pluralistic theories can take a variety of forms, but they share a rejection of what have been called 'monist' accounts of advantage; that is, they reject the idea that all advantages and disadvantages can, in principle, be reduced to a single scale. ${ }^{27}$ As a result, pluralistic theories face difficult questions about 'indexing' - for example, identifying whether $\mathrm{X}$ is worse off than $\mathrm{Y}$ - that monist theories usually avoid. However, defenders of pluralistic theories typically maintain that these conceptual difficulties respect, rather than gloss over, the genuine moral complexities here.

In this sense, Marx's account of human flourishing looks pluralistic. Marx not only offers a diverse account of the components of human flourishing (see below), but also allows that these components might be realized in a variety of ways. He nowhere suggests, for example, that intellectual exercise can only take one form, or that a lack of it might be compensated for by an increase in emotional fulfilment (still less that these two might be traded off against each other because they are reducible to some third metric, say subjective preference satisfaction). Moreover, Marx's occasional engagement with contemporary 'monistic' theories appears emphatically and pertinently critical. For instance, the idea that all that is valuable in social interaction might be reducible to 'the relation of utility' - as if 'love' and 'language' were merely the 'disguises' worn by utility - is treated as an 'absurdity' (first fully formulated by Bentham). ${ }^{28}$ The popularity of this absurdity is sometimes linked, by Marx, to the ways in which capitalist society increasingly treats all aspects of human life as if they were reducible to a financial value. ${ }^{29}$

Third, the capability approach is sometimes characterized as committed to 'normative individualism'; namely, the thought that the social bearers of ultimate value are individuals rather than aggregate entities. Nussbaum makes this point by insisting that the capability approach respects the principle that each person is to be 'treated as an end'. ${ }^{30}$ Others have expressed the relevant claim in terms of the advantage of each and every individual being the focus of 'ultimate concern', the impact on other entities being relevant only 'insofar as, and to the extent that, they affect the interests of individuals, ${ }^{31}$

It is increasingly recognized that Marx is a normative individualist in something like this sense: that - as the gendered language of the literature has it - he is concerned with 'the development of men, not of Man'. ${ }^{32}$ This commitment is apparent in both his critique of contemporary society and his vision of a communist future. Marx criticizes the existing division of labour for, amongst other failings, frustrating 'the all-round development' of the individual. Capitalism's productivity grows, but workers are increasingly chained to a narrow specialism, developing only a fragment of their many-sided potentials. And, despite some occasionally communitarian sounding language, and some

\footnotetext{
27 See Wolff and de-Shalit 2007: ch. 1. See also Nussbaum 2011a: 19.

28 Marx and Engels 1976: 409. ${ }^{29}$ Ibid.: 412-413. ${ }^{30}$ Nussbaum 2001: 55-59.

31 Robeyns 2016: 12.32 Elster 1985: 8. See also Nussbaum 2001: 73-74.
} 
debate about the precise mechanisms here, Marx assumes that the social structures of future communist society will reconcile individuality and community. Indeed, he maintains that 'only within the community has each individual the means of cultivating his gifts in all directions' ${ }^{33}$ This normative individualism is occasionally expressed in a self-consciously Kantian-sounding vocabulary. For example, Marx refers to the existence of a 'categorical imperative' covering the impermissibility, both of systematically treating people as if they were objects, and of failing to treat people as ends (as happens, he insists, in contemporary capitalist society). And he maintains that the starting point for all serious social criticism is "the categorical imperative to overthrow all conditions in which man is a debased, enslaved, neglected and contemptible being, ${ }^{34}$

\subsection{Substantive Affinities}

In order to explore some substantive affinities between Marx and the capabilities approach, I turn to his account of human flourishing. ${ }^{35}$ I will outline the various 'beings' and 'doings' that might be said to constitute his list of 'central capabilities'.

Some proponents of the capability approach appear as if they would prefer to do without such lists. However, I suspect that the real concern here is with the standing of lists - their being dictated from above, for instance - rather than their existence per se. Indeed, since functionings, as such, are morally neutral, identifying those particular functionings which are significant components of well-being - which, of course, is what lists do-looks to be a precondition for the approach to have the kind of constructive and critical purchase it seeks. That said, the kind of list required might well depend on the context in which the capabilities approach is being used, and we should perhaps think of such lists as being open-ended, as subject to democratic revision rather than being 'fixed and final'. ${ }^{36}$

Others might accept the need for such lists, but suspect that we have more than enough lists already. ${ }^{37}$ However, there are a number of justifications for sketching Marx's account here. First, it seems an effective way to pursue the question of his substantive affinities with the capabilities approach. Second, there are those including those who see an 'overlapping consensus' around a list as establishing, or enhancing, its legitimacy or worth - for whom Marx's approval of items on their own list might count for something. And third, Marx's account might provide some critical purchase on other lists; he might, for example, be alert to aspects of human flourishing which others are inclined to underestimate.

Some fourteen requirements for human flourishing can be found in Marx's writings. In order to structure that long list, I group some of these items together,

33 Marx and Engels 1976: 78. $\quad{ }^{34}$ Marx 1975b: 182.

35 This section draws on Leopold 2007: ch. $4 . \quad{ }^{36}$ Sen 2005: 160.

37 For an illuminating survey, see Alkire 2005: 78-82. 
and offer comments on both those subsets and the list as a whole. His account of what might be called basic needs, includes:

(a) Sustenance: Marx talks about 'eating, drinking' and, more generally, of the need for 'nourishment'. 38

(b) Warmth and shelter: Marx lists the need for 'heating' and 'clothing', as well as for a 'dwelling', 39

(c) Certain climatic conditions: Marx mentions the need for both 'light' and 'air'. 40

(d) Movement: Marx speaks of the need 'to move about' and for 'physical exercise'. 41

(e) Basic hygiene: Marx refers to 'the simplest animal cleanliness'. ${ }^{4}$

(f) Sexual activity and reproduction: Marx writes of 'procreation' and describes sexual relationships as characteristic of the 'species'. 43

These basic needs might have a minimal and uncontroversial look, but Marx insists that they are not always met, even in the most economically advanced parts of contemporary Europe. (That Marx's 'animating concern' is frequently with poverty, with those who are worst off, does not, of course, rule out his also being concerned with inequality, with those who are worse off than others. ${ }^{44}$ The need for light and air, he remarks, is not satisfied by 'the pestilential atmosphere of English basement dwellings', and the need for warm clothing is scarcely fulfilled by 'the fantastic rags in which the English poor are clothed' ${ }^{45}$ Indeed, at one point, he conjectures that the 'savage' and the 'animal' may do better than the inhabitants of the 'little Ireland' found in the larger industrial towns of France and England. ${ }^{46}$ As this last remark confirms, these basic needs may be shared with non-human animals. This does not make them any less 'human', but Marx does express concern about situations in which an individual has no other aim than to satisfy basic needs, in which they are reduced to 'nothing more than an animal' ${ }^{47}$ An individual so 'burdened' would regrettably neglect more refined human needs. ${ }^{48}$ These include:

(g) Recreation: Marx refers to the need to 'go drinking', to 'go dancing', to 'fence', to 'sing', 49

(h) Culture: Marx mentions the need to 'go to the theatre'. 50

(i) Education and intellectual exercise: Marx writes of the need to 'think', to 'theorise', to 'buy books', to engage in 'learning'. 51

(j) Artistic expression: Marx notes the need to 'paint'. ${ }^{52}$

(k) Emotional fulfilment: Marx talks of 'love'. 53

\footnotetext{
38 Marx 1975e: 275. ${ }^{39}$ Marx 1975e: 275. ${ }^{40}$ Ibid.: $308 .{ }^{41}$ Ibid.: $308-309 . \quad{ }^{42}$ Ibid.: 308.

43 Ibid.: 275; and Marx 1975a: 172.

44 The phrase is borrowed from a description of Sen in Cohen 1994: $125 . \quad{ }^{45}$ Marx 1975c: 193.

46 Marx 1975e: 308. ${ }^{47}$ Marx 1975e: $275 .{ }^{48}$ Ibid.: $302 .{ }^{49}$ Ibid.: $309 .{ }^{50}$ Ibid.

51 Ibid. Note also Marx and Engels 1975: 89. $\quad 52$ Marx 1975e: $309 . \quad 53$ Ibid.
} 
(1) Aesthetic pleasure: Marx identifies 'a musical ear, an eye for the beauty of form' among our essential human powers. ${ }^{54}$

I take Marx to be providing historically and culturally specific examples of more universal needs which can also be characterized more abstractly (as I have done here). ${ }^{55}$ That Marx is not always recognized as recognizing and seeking to protect these more refined needs is regrettable, since they constitute part of his account of a fully human life. Two additional 'central capabilities' are more often acknowledged as parts of Marx's account of human flourishing. And I will discuss them in turn:

(m) Fulfilling work.

(n) Meaningful community.

The issue of creative and fulfilling work is hugely important to Marx. He sees work as fundamental to human life, and rejects what has been called the 'Christian' view of work as a 'curse' (a punishment for the Fall). The good life involves, not an escape from labour, but rather its transformation into a self-realizing activity, expressive of the kind of creatures we are. The features of work in contemporary society which make it detrimental to self-realization are many - including the 'overwork' which results in the early death of workers - but Marx focuses on the alienated character of modern labour. ${ }^{56}$

Alienation, roughly speaking, refers to the separation of things which properly belong together, and, so understood, alienation always involves a loss (the lack of appropriate connectedness between the relevant entities). Marx famously elaborates four dimensions of alienated labour in the modern world. The first separation is between the modern worker and their product; invoking the idea of fetishism, Marx describes the product of the worker's labour as confronting him 'as an alien object that has power over him'. ${ }^{57}$ The second separation is between the worker and the process or activity by which that product is created; in production, the modern worker is said to relate "to his own activity as something which is alien and does not belong to him'. ${ }^{58}$ The third separation is between the worker and other individuals; this 'estrangement of man from man' is reflected in the way that each individual 'regards the other' as simply a means to his own ends (concern for others surviving only in the pale and inadequate form of a calculation about the effect those others might have on our own self-interest). ${ }^{59}$ The fourth separation is between the worker and human nature; since humankind is a productive species (with the capacity to produce in conscious, free and creative ways), when work becomes only a means to

54 Ibid.: 301.

55 Note that the alternative 'historicist' tradition need not reject the kind of universal list of central capabilities outlined here. See Sayers 1998: 157-159.

56 Marx 1975c: 193.

57 Marx 1975e: 275. Somewhat reluctantly, I follow the gendered language of Marx and (more often) his translators here.

58 Marx 1975e: 275.59 Ibid.: 277-278. 
survival the individual is 'estranged from his own essence', the essential nature of the worker is turned into something alien. ${ }^{60}$

At one point, Marx provides a positive, albeit fleeting, glimpse of what unalienated labour might look like in a future (communist) society where 'we had produced as human beings'. ${ }^{61}$ His elucidating remarks can be read as corresponding to the four dimensions of alienated labour just noted. Regarding the relation between the worker and his product, Marx claims that in self-realizing work, my 'personality' would be made 'objective' in my product, that my creations would embody my talents and abilities in a 'sensuous perceptible' form. ${ }^{62}$ Regarding the relation of the worker to the productive process, Marx maintains that in the productive process I would have demonstrated my 'individuality', that is, have expressed my authentic talents and abilities (making productive activity 'true' to my character). ${ }^{63}$ Regarding the relation between the worker and other individuals, Marx insists I would have produced an object 'corresponding to the needs of another human being', and both parties would recognize and gain satisfaction from that fact. ${ }^{64}$ And regarding the relation between the worker and human nature, Marx suggests that in having 'created an object corresponding to the need of another man's essential nature', I would have united other individuals with their own essential nature. ${ }^{65}$

Meaningful community is also a crucial constituent element of human flourishing for Marx. Commentators sometimes seek some initial purchase on his account by appealing to a familiar Teutonic contrast between Gesellschaft (an 'association' formed in order to advance the self-regarding interests of the individuals who compose it) and Gemeinschaft (a 'community' who share values and a way of life, identify with the group and its practices, and recognize each other as members). ${ }^{66}$ This distinction is not without utility, but this account of community still under-describes what Marx has in mind. Community, for Marx, seems additionally to require that some (imprecisely identified) equality obtains between members, and that they operate with a genuine concern for one another. ${ }^{67}$ This latter involves something more than individuals receiving the reciprocal benefits of co-operation (a model of community that Marx associates with political economy). ${ }^{68}$ It is not enough that others happen to benefit from the (selfregarding) actions of the individual, the latter must also act, in part, in order to help those others fulfil their needs. ${ }^{69}$

Marx portrays the modern world as failing to sustain community of the right kind. (Hereafter, by 'community' I mean 'community of the right kind'.) Community is not wholly absent from the modern world, but it finds only partial and problematic expression there: first, in the democratic state (where it is

${ }^{60}$ Marx 1975d: 220. ${ }^{61}$ Ibid.: 227. ${ }^{62}$ Ibid. ${ }^{63}$ Marx 1975d: $228 .{ }^{64}$ Ibid. ${ }^{65}$ Ibid.

${ }^{66}$ Here I have learnt from, and lean on, the contrast between 'ordinary' and 'moralized' concepts of community outlined in Mason 2000: ch. 1.

${ }^{67}$ See, e.g., Marx 1975a: 164.

${ }^{68}$ See Marx's comments on Smith and de Tracy in Marx 1975d: 217.

${ }^{69}$ See Marx 1975e: 276; and Marx 1975d: 228. On the relation between reciprocity and community, see also Taylor 1982: 28-33. 
abstractly acknowledged before being systematically undermined by the selfseeking and inequality endemic in modern economic life); and second, in the social interaction of radicalized workers (who get to experience fleetingly 'the brotherhood of man'). ${ }^{70}$ This is no trivial limitation. Marx refers to individuals as 'communal' beings, and as having a 'communal' nature. ${ }^{71}$ Consequently, to live in a society which is inhospitable to community is, to that extent, to be estranged from one's own nature. ${ }^{72}$

Marx might be understood as making two claims about the relation between community and human flourishing. Community is not only a condition for individual flourishing, but also a component part of it (hence it has both instrumental and intrinsic value in this context). Living in a community is a necessary requirement for successfully developing and deploying our essential human powers. And such a community is also the result, the product, of the actualization of that human nature. So understood, community is not some 'abstract, universal power standing over against the solitary individual' (like the modern state), but rather an expression of 'the essence of every individual, his own activity, his own life, his own spirit'. 73 To be separated from community is consequently to lead 'a dehumanised life', to suffer a 'far reaching, unbearable, terrible and contradictory' separation from our own nature. $^{74}$

\subsection{Possible Criticisms}

I have suggested that the valuable functionings combining to make up Marx's account of human flourishing require satisfying the need for sustenance, warmth and shelter, certain climatic conditions, physical exercise, basic hygiene, procreation and sexual activity, recreation, culture, intellectual stimulation, artistic expression, emotional satisfaction, aesthetic pleasure, fulfilling work and meaningful community. However, there seems no good reason for Marx to resist the characterization of this list as open-ended and subject to revision. I do not suggest that he would have viewed all putative additions favourably, only that there is no evidence that he considered these scattered remarks on human flourishing to provide a comprehensive enumeration of its component parts. That said, Marx's summary list invites additional comment, concerning what might be called omissions, emphasis and status.

By 'omissions' I mean whether Marx's list omits any important capabilities. One might consider whether he misses any component from the best-known of modern lists, namely, Nussbaum's ten 'Central Capabilities' (the phrase is capitalized here when the reference is to Nussbaum's list): life; bodily health; bodily integrity; sense, imagination and thought; emotions; practical reason; affiliation; other species; play; control over one's environment. ${ }^{75}$ The overlap here with Marx appears

\footnotetext{
70 Marx 1975e: $313 . \quad{ }^{71}$ See, e.g., Marx 1975a: $155 . \quad{ }^{72}$ See Marx 1975d: $217 .{ }^{73}$ Ibid.

74 Marx 1975c: 205. ${ }^{75}$ Nussbaum 2011a: 33-34.
} 
considerable, and, in most cases, apparent differences concern the grouping of items rather than serious disagreement about the good life (although see below). Concern for other species might look like an 'omission', but even here some rapprochement seems possible. Marx's appreciation that human flourishing requires an appropriately unalienated relation to (the rest of) the natural world seems to fit with Nussbaum's valuation of 'being able to live with concern for and in relation to animals, plants, and the world of nature'. ${ }^{76}$

By 'emphasis', I mean whether Marx's list stresses some part of human flourishing at the expense of another. For example, he has been charged with having a severely one-sided account of human flourishing; in particular, emphasizing the active and creative side of human nature (the development and exercise of individual talents and abilities), whilst neglecting 'a whole domain of human need and aspiration', namely the need for, and interest in, unhyphenated 'self definition' (our need to be defined by, or located in, something larger than ourselves). ${ }^{77}$ The issues here are complex, but the key indicator of this insufficient emphasis is said to be treating community only 'as a means' to the independently specified goal of individual self-realization. ${ }^{78}$ However, on the present account, this key indicator is missing, and communal membership is a constituent part of (as well as a means to) human flourishing. Marx rejects the view that 'the essential bond' joining individuals together is something 'inessential', a mere means to the satisfaction of individual interests; indeed, he identifies such a view as a likely product of circumstances in which the communal aspects of human nature are underdeveloped or frustrated. ${ }^{79}$

By 'status', I mean whether Marx's list is problematically perfectionist. Perfectionist moral standpoints value the development and deployment of certain human capacities (for artistic expression, for example) apart from any pleasure or happiness that they might bring (and so are usually understood as objective theories of the good). Marx does appear to occupy a perfectionist position, and those who frame the capabilities approach as a form of Rawls-inspired 'political liberalism' are likely to be suspicious; not least, disapproving of Marx for offering a (partially) comprehensive conception of the good life, and not just a view about our role as citizens in a pluralistic society. Indeed, Nussbaum has recently only hesitantly allowed that Marx's views might count as a 'reasonable' comprehensive doctrine that, as part of a pluralistic society, would over time play a role in an 'overlapping consensus' committed to a 'freestanding' constitutional scheme of the right kind. ${ }^{80}$ (That hesitancy is perhaps caused by her belief - mistaken, in my judgement - that Marx 'probably would not endorse' items such as 'expressive and associative liberty, and the freedom of worship'. ${ }^{81}$ However, on the plausible assumption that the capabilities approach contains both perfectionist and non-perfectionist strands, Marx's apparent endorsement of perfectionism would not, in itself, undermine the affinities here.

\footnotetext{
76 On the latter, see Benton 1993; Foster 2000; Hughes 2000. ${ }^{77}$ Cohen 1988: 137.

78 Ibid.: 143. ${ }^{79}$ Marx 1975c: $217 .{ }^{80}$ See Nussbaum 2011b: 34 n. 55.

81 Nussbaum 2001: 72 .
} 


\subsection{Critical Purchase}

Having responded, albeit briefly, to those concerns, I want to flesh out the earlier suggestion that Marx's substantive list might have some critical purchase on the work of others. Not least, to consider whether Marx's list might not only draw attention to particular capabilities that are omitted or underemphasized by others, but also raise some pertinent questions about the 'demandingness' of thresholds.

The issue of omissions might appear redundant, given the broad overlap said to obtain between Marx's list and the 'Central Capabilities', but the question of underemphasis remains. In particular, one might wonder - in the light of Marx's account - whether both community and work appear in somewhat insubstantial form in some contemporary lists. (Matters of emphasis are not easy to judge, and the following remarks are intended tentatively to raise the question, and not decisively to answer it.)

Community appears to be included in the 'Central Capabilities' under the category of 'affiliation', which requires associational freedom and nondiscrimination, and perhaps includes the idea of sharing in common projects. ${ }^{82}$ This kind of 'affiliation' is said to involve recognizing others, being able to imagine their situation, and showing concern for them. ${ }^{83}$ However, there is no obvious requirement for community here to involve background economic equality, or that we act (reciprocally) with a genuine (not merely instrumental or self-serving) concern for other persons. On Marx's account, 'affiliation' might seem to suggest a familiar but somewhat etiolated notion of community which remains compatible with economic inequality and (enlightened) self-seeking.

Work appears to be included in the 'Central Capabilities' under the subdivision of 'material', as distinct from 'political', 'control over one's environment'. This control seemingly requires property rights in land and moveable property, and that we are each able to work 'as a human being ${ }^{84}$ - the latter involving both the exercise of 'practical reason' and relationships of 'mutual recognition' with co-workers. ${ }^{85}$ These requirements are, importantly, not without weight - for instance, they might rule out child labour and sexual harassment in the workplace - but they do not obviously require creative and fulfilling work. ${ }^{86}$ Elsewhere, Nussbaum insists that human dignity has 'clear implications for economic conditions and conditions of work', but what she specifically denounces is people being put 'to work in substandard conditions in order to maximise profit'. ${ }^{87}$ Again, these are vital moral issues, but they could be addressed without requiring work to be creative and fulfilling.

In short, whilst Marx's account of community and work might resonate with Nussbaum, there remains some doubt whether she has built his concerns fully into her most recent accounts of the requirements of human dignity. I write 'most recent' because, although there is insufficient space to pursue the idea here, it seems possible that in writings predating her turn towards 'political liberalism',

82 See Nussbaum 2011a: $99 . \quad{ }^{83}$ Ibid.: $34 . \quad{ }^{84}$ Nussbaum 2011a: $34 . \quad{ }^{85}$ Ibid.

86 For child labour and sexual harassment, see ibid.: 72, 141. ${ }^{87}$ Nussbaum 2006: 277. 
Nussbaum had 'thicker' notions of work and community in mind. ${ }^{88}$ (Of course, the associated suspicion is that there is some explanatory connection between that turn and the weakening of those commitments.)

These differences between Nussbaum and Marx seem to concern not only the interpretation of particular items on the list (here, work and community), but also their respective views about the appropriate demandingness ('height') of the threshold being set. Both authors seem to be thinking of a threshold that applies to all citizens, and which societies are under an obligation to meet. However, Marx appears to place that threshold higher than Nussbaum; witness his more demanding notions of fulfilling work and meaningful community.

Nussbaum suggests that there are two dangers to be avoided in setting a threshold. The first danger is 'lack of ambition'; that is, setting the threshold so low that it is easy to meet. ${ }^{89}$ The second danger is 'utopianism'; that is, setting a threshold that 'no nation could meet under current world conditions'. ${ }^{90}$ Her own choice of a threshold determined by the conditions for 'dignity' is, perhaps predictably, said to fall between these two extremes; it is 'aspirational but not utopian'. ${ }^{91}$ But what about Marx's proposed threshold?

Whether Marx is guilty of 'utopianism', on this account, is surprisingly hard to determine. Part of the difficulty here is in unpacking the claim that it is unhelpfully 'extreme' to set a threshold that 'no nation could meet under current world conditions' (call this Nussbaum's 'current conditions proviso'). ${ }^{92}$ On what we might call a concessive reading (concessive, that is, to existing states of affairs), we might treat the current conditions proviso as recommending that we aim no higher than someone else has already reached. Such a reading - on which contemporary thresholds could be extended but not raised - would seem to cap progressive social change at an arbitrary and incomplete level. Most nations might still aspire to the social minimum of, say, Sweden or Finland, but nothing more. It seems unlikely that this can be Nussbaum's view. ${ }^{93}$ Not least, full sex equality does not exist in any contemporary society, and its introduction would seem to require radical social and political change, even in those societies which currently do much better than others. Yet it seems certain that Nussbaum would not want us to conclude that sex equality is ruled out as a problematically 'utopian' goal. ${ }^{94}$ However, the precise contours of an alternative (and less concessive) reading - one that would allow (certain kinds of) radical social change to be consistent with the current conditions proviso - are not clear to me. In the absence of that clarification, it is hard to discern whether Marx's understanding of meaningful community and fulfilling work - as a result of the dramatic change to 'current conditions' they would require - are in violation of Nussbaum's proviso.

More generally (and putting that specific proviso aside), I should note my rejection of certain familiar portraits of Marx as 'utopian' in the sense of being

88 See, e.g., the discussion of work in Nussbaum 1990: 231. $\quad{ }^{89}$ Nussbaum 2011a: $42 . \quad{ }^{90}$ Ibid.

91 Ibid. ${ }_{92}$ Ibid. 93 Although, for Scandinavian enthusiasms, see Nussbaum 1990: 240-242.

94 Similarly, Rawls's goals are treated as not utopian, despite their presumably requiring radical transformation of existing societies. Nussbaum 2011a: 76. 
hopelessly unrealistic about the limits of human perfectibility. Fulfilling work and meaningful community, for instance, are undoubtedly demanding conditions, but they are not obviously incompatible with what is known about human nature and social design (not obviously infeasible). ${ }^{95}$ It is sometimes suggested that Marx envisaged a future (communist) society as overcoming all possible sources of individual discontent, frustration, conflict, anxiety and so on. ${ }^{96}$ However, as presented here, Marx's account of human flourishing scarcely confirms that extravagant picture. A society which fulfilled Marx's threshold conditions for human flourishing would still contain difficult choices between incommensurable goods, to say nothing of its share of unrequited lovers, moral and other disagreements, and the possibility of serious accidents and illnesses befalling friends and family members. Marx's vision of a rational and humane future is demanding, but it is also one in which - the critic can be reassured - plenty of room for sadness will remain.

\section{$2.8 \quad$ Concluding Remarks}

The capabilities approach is often said to be at an early and fluid stage in its development, and there undoubtedly remains scope to refine our understanding of its character and history. In the present chapter, having responded to some initial scepticism, I have sought to identify and explore some connections between that approach and Marx's work. Those efforts are far from exhaustive. Most obviously, I have focused on Marx's account of human flourishing and said little about the institutional and other arrangements that he viewed as necessary for its widespread realization. ${ }^{97}$ However, this discussion still has some significant exegetical and critical ambitions.

I hope to have fleshed out some of the positive connections between Marx and the capabilities approach, connections which remain understudied by comparison, say, with those involving Aristotle. In particular, I sketched certain shared concerns, before identifying some formal and substantive affinities between Marx's work and the capabilities approach. These shared concerns and affinities would seem to lend support to the exegetical claim that much in the character and content of Marx's work is consistent with, and similar to, elements of the capabilities approach. (They might also justify further historical work in order to assess whether, and how, Marx's writings came to influence the relevant modern theorists.)

I have also raised the possibility that Marx's writings might provide a critical perspective on some contemporary versions of the capabilities approach. We can interpret him as cautioning against too limited an account both of particular

95 They are, after all, capable of being realized, albeit partially, within certain class-divided societies.

96 See, e.g., Kolakowski 1978: 523.

97 For a critique of Sen focusing on these institutional arrangements, see Fraser 2016. 
ingredients of the good life, and the wider conditions for a fully human existence. Marx's insistence on the importance and value of fulfilling work and meaningful community draws attention to particular capabilities that might be omitted or underestimated by others. And his account of the threshold conditions of the good life warns us, more generally, that, in pursuing the social and other changes that might best promote human flourishing, we should not set our sights too low. ${ }^{98}$

\section{References}

Alkire, S. 2005. Valuing Freedoms: Sen's Capability Approach and Poverty Reduction. Oxford University Press.

Benton, T. 1993. Natural Relations: Ecology, Animal Rights and Social Justice. London: Verso.

Cohen, G. A. 1988. History, Labour and Freedom: Themes from Marx. Oxford University Press.

1994. 'Amartya Sen's Unequal World'. New Left Review I/203: 117-129.

Elster, J. 1985. Making Sense of Marx. Cambridge University Press.

Foster, J. B. 2000. Marx's Ecology: Materialism and Nature. New York: Monthly Review Press.

Fraser, I. 2016. 'Sen, Marx and Justice: A Critique'. International Journal of Social Economics 43/12: 1196-1206.

Geras, N. 1986. Literature of Revolution: Essays on Marxism. London: Verso.

Hughes, J. 2000. Ecology and Historical Materialism. Cambridge University Press.

Kolakowski, L. 1978. Main Currents of Marxism, vol. III: The Breakdown. Oxford University Press.

Leopold, D. 2007. The Young Karl Marx: German Philosophy, Modern Politics, and Human Flourishing. Cambridge University Press.

Lukes, S. 1987. Marxism and Morality. Oxford University Press.

McMurtry, J. 1978. The Structure of Marx's World-View. Princeton University Press.

Marx, K. 1975a. 'On the Jewish Question', in Karl Marx, Frederick Engels: Collected Works, vol. III. London: Lawrence \& Wishart: 146-174.

1975b. 'Contribution to the Critique of Hegel's Philosophy of Law: Introduction', in Karl Marx, Frederick Engels: Collected Works, vol. III. London: Lawrence \& Wishart: 175-187.

1975c. 'Critical Marginal Notes on the Article "The King of Prussia", in Karl Marx, Frederick Engels: Collected Works, vol. III. London: Lawrence \& Wishart: 189-207.

1975d. 'Comments on James Mill', in Karl Marx, Frederick Engels: Collected Works, vol. III. London: Lawrence \& Wishart: 211-228.

1975e. 'Economic and Philosophic Manuscripts of 1844', in Karl Marx, Frederick Engels: Collected Works, vol. III. London: Lawrence \& Wishart: 229-346.

1989. 'Critique of the Gotha Programme', in Karl Marx, Frederick Engels: Collected Works, vol. XXIV. London: Lawrence \& Wishart: 75-99.

98 I am grateful to Jan Kandiyali, Mozaffar Qizilbash, Lucinda Rumsey, Sean Sayers and an anonymous reviewer, for helpful comments on an earlier draft. 
Marx, K. and Engels, F. 1975. 'The Holy Family', in K. Marx and F. Engels. Collected Works. London: Lawrence \& Wishart: vol. IV, 5-211.

1976. 'The German Ideology', in K. Marx and F. Engels. Collected Works. London: Lawrence \& Wishart: vol. V, 19-539.

Mason, A. 2000. Community, Solidarity and Belonging: Levels of Community and their Normative Significance. Cambridge University Press.

Nussbaum, M. 1990. ‘Aristotelian Social Democracy', in R. Bruce Douglass, G. M. Mara and H. S. Richardson (eds.). Liberalism and the Good. London: Routledge: 203-252.

2001. Women and Human Development: The Capabilities Approach. Cambridge University Press.

2006. Frontiers of Justice: Disability, Nationality, Species Membership. Cambridge, MA: Harvard University Press.

2011a. Creating Capabilities: The Human Development Approach. Cambridge, MA: Harvard University Press.

2011b. 'Perfectionist Liberalism and Political Liberalism'. Philosophy \& Public Affairs 39/1: 3-45.

Qizilbash, M. 2006. 'Capability, Happiness and Adaptation in Sen and J. S. Mill'. Utilitas 18/1:20-32.

2016. 'Capability, Objectivity and "False Consciousness": On Sen, Marx and J. S. Mill'. International Journal of Social Economics 43/12: 1207-1218.

Robeyns, I. 2016. 'Capabilitarianism'. Journal of Human Development and Capabilities 17/ 3: $1-18$.

Sánchez Garrido, P. (2008) Raíces intelectuales de Amartya Sen. Aristóteles, Adam Smith y Karl Marx. Madrid: Centro de Estudios Políticos y Constitucionales.

Sayers, S. 1998. Marxism and Human Nature. London: Routledge.

Sen, A. 1988. The Standard of Living (ed. G. Hawthorn). Cambridge University Press.

1994. 'Amiya Kumar Dasgupta (1903-1992)'. The Economic Journal 104/426: $1147-1155$.

1997a. Resources, Values and Development. Cambridge: Harvard University Press.

1997b. Choice, Welfare, and Measurement. Cambridge: Harvard University Press.

2001. Development as Freedom. Oxford University Press.

2003. 'Sraffa, Wittgenstein, and Gramsci'. Journal of Economic Literature 41/4: $1240-1255$.

2005. 'Human Rights and Capabilities'. Journal of Human Development 6/2: 155-166.

2009. The Idea of Justice. London: Penguin.

Skinner, Q. 2002. 'Meaning and Understanding in the History of Ideas', in Visions of Politics: Regarding Method. Cambridge University Press.

Sumner, L. W. 2006. 'Utility and Capability'. Utilitas 18/1: 1-19.

Taylor, M. 1982. Community, Anarchy and Liberty. Cambridge University Press.

Wolff, J. and de-Shalit, A. 2007. Disadvantage. Oxford University Press.

Wood, A. W. 1981. Karl Marx. London: Routledge: ch. 9. 